\title{
SELF-ASSESSMENT OF COMMUNICATION SKILLS BY MANAGEMENT STUDENTS: AN EMPIRICAL STUDY IN INDIAN CONTEXT
}

\author{
Kajal Srivastava \\ Department of Business Communication, Faculty of Business Communication, Jaipuria Institute of \\ Management, India \\ E-mail: kajal.srivastava@jaipuria.ac.in
}

APA Citation: Srivastava, K. (2018). Self-assessment of communication skills by management students: An empirical study in Indian context. English Review: Journal of English Education, 6(2), 11-18. doi: 10.25134/erjee.v6i2.1239.

Received: 18-02-2018

Accepted: 21-04-2018

Published: 01-06-2018

\begin{abstract}
Communication skills are most sought after by the business world and are considered to be vital for personal and professional growth. There have been many researches on the importance of communication skills and how they act as catalysts in getting a job or a dream job. Furthermore, employers, institutes and universities also emphasise that an individual apt at communication skills is more likely to get a job in comparison to one who is not. This study is meant to decipher the communication skills of management trainees at the time of joining the institute through a selfappraisal questionnaire. The research design employed was Descriptive Cross-Sectional. 125 students were chosen from five management institutes in Lucknow (India) by employing non-random Convenience Sampling. Findings indicated that there is an overall fear of public speaking, respondents fall short of words while writing in English and need to be encouraged to read more English magazines and novels. Conclusively, a curriculum may be designed wherein the faculty, along with inputs of the students can build a framework with a view to maximising public speaking activities, and other activities may focus upon reading and writing. Moreover, peer-feedback is recommended to enhance reflective learning.
\end{abstract}

Keywords: management students, active listening skills, oral communication skills, communication building strategies, public speaking

\section{INTRODUCTION}

Communication skills are one of the most desired factors affecting employability and career progression. It is considered to be an essential trait by the employers as well.

Hence, the curriculum of every Management institute lays proper emphasis on honing communication skills of their students. Thus, management institutes also serve as centres where existing communication skills of students are further improved for placement purposes. As it is, prospective employers reiterate the fact that students need to have their listening and speaking skills refined (Weldey, \& Icenogle, 2016). Employers seek candidates who have effective interpersonal communication skills (Golen, Catanach, \& Moeckel, 1997).
Communication is a process wherein a message, which may be verbal, non-verbal or both, is transferred orally or verbally by the sender to the receiver. In return, the receiver gives a response or feedback (Masri, 1997).Communication, in other words, refers to the tact and ability to transfer or convey information effectively and efficiently. Yet, for an effective communication, one needs to be skilled in listening, speaking, reading and writing. These four skills happen to be the parameters on which an individual's abilities to communicate may be evaluated.

Communication may be done in two ways; orally or written. The former includes speaking and listening wherein the sender delivers the message orally and the receiver listens. This is followed by an oral feedback 


\section{Kajal Srivastava}

Self-assessment of communication skills by management students: An empirical study in Indian context

(examples are; in a meeting, over the cellphone, in an interview, etc.) by the receiver. The latter includes writing and reading wherein the sender conveys a message in a written format (an e-mail, letter, memo, text or fax) and the receiver sends a response after having read/interpreted the message. The skills involved in this process are writing and reading.

With specific reference to the business world, managers need to be adept in both written and oral communication in order to facilitate transfer of information between people within an organisation and outside it as well. Communication is vital in light of the fact that every managerial role involves one or the other form of oral or written

communication or both. Communication skills are important for growth and career progression of individuals as well. A research study concluded that recruiters rated communication skills as the most important characteristic of an ideal job candidate (Yate, 2009).Abundant research has proved that communication skills are essential for managers (Bradshaw, 1992; Prentice, 1984, Margerison \& Kakabadse,

1984).Communicative abilities are crucial for advancement in career and success in the organization (Cohen, 1999; Messmer, 1999; Warner, 1995; Roebuck et al., 1995; Flatley, 1990; Curtis et al., 1989). In earlier studies, Bass (1990) and Kanter (1983) pointed out a clear relationship between competence in communication and managerial effectiveness.

Further, communication skills of every individual affect both personal and organizational effectiveness (Brun, 2010; Summers, 2010). Effective communication skills are most essential for personal as well as organizational growth. It is therefore only rational to state that one of the most impeding forces to organizational efficiency is the lack of effective communication (Lutgen-Sandvik, 2010). In addition to this, special emphasis is laid on oral communication skills during the process of hiring (Maes, et al., 1997). Another study found that senior HR managers wanted their employees to be effective in interpersonal communication. However, it was found that these managers lacked in the art of listening and taking lead in a collaborative manner (Bambacas \&Patrickson, 2008). Therefore, in order to be an effective manager, studies have acknowledged the fact that effective communication skills are an absolute must.

Furthermore, since the current generation lives in a global village where communication is the key to negotiation, achieving targets and desired goals, managerial students need to hone their existing communication skills in order to carve a niche for themselves. Students need to gain expertise in communication skills with specific reference to a milieu of cultures that are existent and in the current workplace scenario (Penbuk, Yurdakul \& Cerit, 2009). In addition to this, according to Harleket al. (2008), students at university level should participate in activities that are capable of developing their communication skills beginning from the very first year in the university.

Earlier research on communication skills among university students has been conducted by Cleland, Foster and Moffat (2005) and Ihmeideh, Ahmad and Dababneh (2010). The results of both research indicated that a positive communication environment gives students opportunities to learn how to communicate thereby improving their communication skills. Hence, the purpose of this paper is to present an empirical research on the self-assessment of management students associated with LSRW skills. The idea is to gain an understanding of their current proficiency levels related to various communication skills. This research focuses specifically on four communication parameters which are; 1)Active listening skills (L), 2) Oral communication skills (S), 3) Communication building strategies (R), and 4) Written communication skills (W).

\section{METHOD}

For the present study, Descriptive Crosssectional Research Design was employed. The survey instrument was a closed ended questionnaire. In this research, 125 students of five management institutes in Lucknow were given self-assessment questionnaires at the 
ENGLISH REVIEW: Journal of English Education Volume 6, Issue 2, June 2018

very onset of their managerial program. Institutes were selected based on the year in which they commenced management education. Five oldest management institutes were selected for the study. Apart from their age, their occupancy ratio was also taken into consideration and all selected institutes had a history of $100 \%$ filled seats as per their allocation by the concerned authorities/agency.

Within the institutes, 25 students were selected on the basis of their interest for participation in the study. The students were explained about the research, its objective and based on their willingness, 25 students were selected from each institute. Non-random Convenience Sampling has been employed for the selection of the sample.

The questionnaire comprised of 20 statements which were meant to evaluate various communication skills. Of these, four statements evaluated students' active listening abilities. These comprised of their comprehension skills related to the spoken word, their responsiveness by asking statements in class after listening and the attention paid to words during conversation. Eight statements were based on students' proficiency in oral communication (speaking). These statements focused on students' confidence in English speaking ability to communicate their point of view, usage of new words while conversing in English, the
p-ISSN 2301-7554, e-ISSN 2541-3643

https://journal.uniku.ac.id/index.php/ERJEE

fear of public speaking, ability to summarize what is being said, using grammatically correct English, and hesitation while speaking in public. Five statements focused on communication building strategies (Reading) which students adopted. These included their habit of reading English newspapers, ability to understand the content displayed in English newspapers, their preference to learn and write new words from the newspaper, watching English news channels, other English channels and their inclination in reading English novels and magazines. Furthermore, three statements assess students' clarity in written communication. These statements focus on students' ability to express their thoughts clearly through the written word, their capability to write grammatically correct English and whether they fall short of words while writing in English. The respondents had to self-assess their communication skills on a five-point Likert scale. Thereafter, mean analysis was done to capture the self-assessment of the respondents.

\section{RESULTS AND DISCUSSION}

The data was collected from 125 respondents, although only 117 questionnaires were found to be complete and were used for the purpose of analysis. The students were from various cities as summarised below.

\begin{tabular}{|c|c|c|}
\hline No & State & Number of respondent \\
\hline 1 & Uttar Pradesh & 87 \\
\hline 2 & Bihar & 11 \\
\hline 3 & Jharkhand & 03 \\
\hline 4 & Uttrakhand & 05 \\
\hline 5 & West Bengal & 08 \\
\hline \multirow[t]{2}{*}{6} & Assam & 03 \\
\hline & Total & 117 \\
\hline
\end{tabular}

Majority of the respondents were from Uttar Pradesh only and amongst them, close to $60 \%$ were from Lucknow only. Others represented cities like Allahabad, Varanasi, Kanpur, Sitapur, Barabanki, Gorakhpur etc. Since the sample size was small, hence, State Wise differences in assessment of communication skill were not considered. follows.
The gender wise representation was as 


\section{Kajal Srivastava}

Self-assessment of communication skills by management students: An empirical study in Indian context

Table 2. Gender representation in sample

\begin{tabular}{llcc}
\hline No & Gender & Number & Percentage \\
\hline 1 & Male & 76 & 65 \\
2 & Female & 41 & 35 \\
\hline
\end{tabular}

Of the total sample $65 \%$ were male while $35 \%$ were female. The gender wise differences in assessment of communication skills were also not considered for analysis. Although it may be an interesting research to be carried in future.

The sample distribution based on their educational background is as follow.

\section{Table 3. Educational background of respondents}

\begin{tabular}{clcc}
\hline No & Education & Number of respondents & Percentage \\
\hline 1 & BA/BSc/B.Com & 78 & 67 \\
2 & BBA & 27 & 23 \\
3 & B Tech. & 08 & 7 \\
4 & Others & 04 & 3 \\
\hline
\end{tabular}

Majority of the respondents had done BA/BSc/B.Com during their graduation. $23 \%$ of the respondents have pursued management education in their graduation stream. Therefore, since the representation of educational background was small, no attempt was made to study the differences in assessment based on their educational background.

Mean Analysis was done on all the statements which were discussed for ease and clarity. First, the results of mean and standard deviation analysis of statements measuring active listening skills (L) are shown below.

Table 4.Mean and standard deviation of statements measuring active listening skills (L)

\begin{tabular}{llcc}
\hline No & Active Listening Skills (L) & Mean & SD \\
\hline 1. & I pay attention to each and every word said by someone else & 3.84 & 0.85 \\
& during conversation & & \\
2. & I listen carefully and full grab the meaning of spoken words. & 3.42 & 0.80 \\
3. & I respond to listening by asking questions in class & 3.09 & 0.94 \\
4. & I comprehend lectures delivered in English & 3.61 & 0.97 \\
\hline
\end{tabular}

The mean values indicate that the respondents pay attention and are able to grasp the meaning of spoken words as indicated by relatively higher values for these statements. Although many of them are not engaged in active discussion or asking questions in the class.

Second, the results of mean and standard deviation analysis of statements measuring oral communicative skills (S) are presented below.

Table 5.Mean and standard deviation of statements measuring oral communication skills $(S)$

\begin{tabular}{llcc}
\hline No & \multicolumn{1}{c}{ Oral Communication Skills (S) } & Mean & SD \\
\hline 1. & I avoid using slang while speaking in English & 3.22 & 0.67 \\
2. & I have hesitation in public speaking & 2.69 & 1.1 \\
3. & I try to make use of new words while speaking in English & 2.93 & 1.00 \\
4. & I speak grammatically correct English & 3.61 & 0.71 \\
5. & I feel confident in speaking in English & 3.37 & 0.83 \\
6. & I find it easy to communicate my point of view to the other person & 3.23 & 0.90 \\
7. & I can easily summarize what I listen to. & 3.37 & 0.84 \\
8. & I have a fear of Public Speaking & 2.70 & 1.1 \\
\hline
\end{tabular}

The mean values listed above are indicative that respondents avoid using slang while speaking in English. It further states that they speak grammatically correct English, they are confident in speaking in English, they communicate views easily and are adept at 
ENGLISH REVIEW: Journal of English Education Volume 6, Issue 2, June 2018

summarizing. However, respondents are hesitant of speaking in public and there is also a fear of public speaking. In addition to this, the usage of new words during conversing is relatively low. The findings may be used to decide the pedagogy and delivery of various
p-ISSN 2301-7554, e-ISSN 2541-3643

https://journal.uniku.ac.id/index.php/ERJEE

Table 6. Mean and standard deviation of statements measuring communication building strategies $(R)$

\begin{tabular}{clcc}
\hline No & \multicolumn{1}{c}{ Communication Building Strategies (R) } & Mean & SD \\
\hline 1. & I watch English news channels and other English channels & 3.15 & 1.20 \\
2. & I am in a habit of reading English Newspapers & 2.54 & 1.08 \\
3. & I understand the content of English newspapers easily & 3.45 & 0.89 \\
4. & I prefer to write and learn new words from the newspaper. & 2.80 & 1.24 \\
5 & I read English novels/magazines & 2.85 & 1.29 \\
\hline
\end{tabular}

When referring to mean values related to reading, respondents are adept at watching English news channels and other English channels as well. Nevertheless, mean values of other parameters such as the habit of reading newspapers, understanding its content, the interest in writing and learning new words and the inclination towards reading English novels and magazines is relatively low. The findings are indicative that courses which may improve effectiveness of the courses and learning of the students.

Third, the results of mean and standard deviation analysis of statements measuring Communication Building Strategies $(\mathrm{R})$ are presented below.

Table 7. Mean and standard deviation of statements measuring written communication skills (W)

\begin{tabular}{llcc}
\hline No & Writing (W) & Mean & SD \\
\hline 1. & I place emphasis on writing grammatically correct English & 4.14 & 0.95 \\
2. & I can express my thoughts effectively by writing in English & 3.81 & 0.90 \\
3. & I fall short of words while writing in English. & 3.12 & 1.07 \\
\hline
\end{tabular}

In the above table, higher mean values are indicative of the fact that respondents place a high emphasis on writing grammatically correct English and are able to express their thoughts clearly in writing. However, the mean value is further indicative of the fact that respondents' fall short of words while writing in English. Looked together since little effort is put by respondents on reading and enhancing their vocabulary it affects their written communication skills as well.

This research aims at finding out the LSRW competency skills among management students through self-appraisal at the commencement of management programmes. On the basis of the questionnaire, there are various implications which are as follows; one the institute should think about how to improve their reading habits, discussion of contemporary news items from newspaper, book review, etc. may be some tools which may be used by institutes.

Fourth, the results of mean and standard deviation analysis of statements measuring written communication skills (W) are presented below. of the implications of the study is the hesitation among students of public speaking. The study points out a definite fear of public speaking among students. The second implication is that of the students having a relatively low mean value as far as reading English novels and magazines and writing new English words is concerned.

The overall idea of the study is to have a self-perception of the students' LSRW competency skills in order for it to be mapped for further research at the end of the course. The basic aim is to identify the weaknesses of the students at the beginning of the programme. Once the students are made aware of their weaknesses, it becomes easier to encourage them to work on these weak areas thereby improving their existing skill 


\section{Kajal Srivastava}

Self-assessment of communication skills by management students: An empirical study in Indian context

sets. According to Sanchez and Hynes (2001), students' perceptions on their existing skill levels provide intricate details on the nature of learning that took place in actuality. Their theoretical framework further assumes that students are the best determinants of how much they learnt. Hill, Mehta and Hynes (2014) further state that self-perceptions about competency levels should be included in learning assessment programs.

On the basis of these results, a third implication is that communication modules and teaching styles may be modified in order to suit the expectations of both the students and their prospective employers. The utility of the study may also be extended to designing curriculum, selecting most suitable pedagogy and choosing the best assessment tools as well. Considering the result of the study as an indicator somehow the students should be encouraged to read more English content either through newspaper or magazine/books. They should also be encouraged to learn new words and their usage while writing.

Further, it should not be assumed that all these four LSRW operate in water tight compartment, in-fact they are interrelated to each other and will mutually drive effective communication hence they operate in a cyclical manner affecting each other and affecting communication skills in general.

\section{CONCLUSION}

This research is indicative of how management students rated their communication skills with respect to LSRW. On the basis of various statements, students were asked to gauge their skill sets on a scale of 1-5 on their active listening skills (L),oral communication skills $(\mathrm{S})$, communication building strategies (R),and written communication skills (W).The analysis leads to a number of conclusions. First, the results are indicative that respondents pay attention and are capable of grasping the meaning of the spoken words in English. The results are also indicative of the fact that slang is avoided by respondents during communication.

Second, the results are also suggestive of the fact that while respondents are adept at watching English new channels, the drive towards reading newspapers and understanding content in novels and magazines is relatively low. Third, peerresponse may be introduced in the classroom activities. The basic idea is to get learners involved in the learning process through peer response and student feedback. This can resultantly promote reflective learning. According to Mezirow (1990, p. 366), reflective learning encourages 'critical reflection in order to precipitate or facilitate transformative learning in adults'. In a similar way, Schon (1991) asserts that reflection can modify traditional learning into an experience. In the process of analyzing their communicative needs, articulating learning preferences, and by giving peer feedback, students become more mindful of what they need to deliver as course participants and develop skills to reflect on their learning process. Also, students' analysis can encourage students by engaging them in thought-provoking and eloquent classroom experiences.

\section{REFERENCES}

Bass, B. M. (1990). Handbook of leadership (3 $3^{\text {rd }}$ ed.). New York: Bass \& Stogdill's Press.

Brun, J. P. (2010). Missing pieces: 7 ways to improve employee well-being and organizational effectiveness. New York, NY: Palgrave Macmillan.

McCroskey, J. C., \& McCroskey, L. L. (1988). Self-report as an approach to measuring communication competence. Communication Research Reports, 5(2), 108-113.

Kanter, R. M. (1983). The change masters. New York: Simon \& Schuster.

Lutgen-Sand vik, P. (2010).Destructive organizational communication: Processes, consequences, and constructive ways of organizing. New York, NY: Routledge.

Bambacas, M., \& Patrickson, M. (2008). Interpersonal communication skills that enhance organisational commitment. Journal of Communication Management, 12(1), 51-72.

Mezirow, J. (1990). Fostering critical reflection in adulthood. San Francisco: Jossey-Bass.

Sanchez, S., \& Hynes, G.E. (2001). Effectiveness of traditional delivery versus online delivery for a managerial communication course. Presented at a Symposium: Assessing the Quality of Online Instruction, Naval Postgraduate School, Monterey, CA. 
ENGLISH REVIEW: Journal of English Education Volume 6, Issue 2, June 2018

Schon, D. A. (1991). The reflexive turn: Case studies in and on educational practice. New York:

Teachers' College.

Masri, S. (1997). Media dan komunikasi dalam bahasa Melayu. Malaysia: Fajar Bakti.

Weldey, T. G., \& Icenogle, M. L. (2016). A managerial perspective: Oral communication competency is most important for business students in the workplace. International Journal of Business Communication, 34(1), $67-80$.

Yate, M. (2009). Hiring the best: A manager's guide to effective interviewing and recruiting. Cincinnati, OH: F \& W Media.
p-ISSN 2301-7554, e-ISSN 2541-3643

https://journal.uniku.ac.id/index.php/ERJEE 


\section{Kajal Srivastava}

Self-assessment of communication skills by management students: An empirical study in Indian context 